\title{
Quality Analysis of a Learning Media Analog Electronics on the Android Platform with ISO 25010
}

\author{
Barry Nur Setyanto *, Mushlihudin, David Yoga Pradana \\ Email : barry.setyanto@pvte.uad.ac.id* \\ *: coresponndensing author \\ Univesitas Ahmad Dahlan, Jl Pramuka No. 42, Pandeyan Umbulharjo, Yogyakarta, Indonesia
}

\section{ARTICLE INFO}

Article history

Received Apr 30, 2021

Revised May 26, 2021

Accepted May 31, 2021

Keywords

Analog Electronic

Learning Media

Android

Compatibility Aspect

Performance Efficiency Aspect
ABSTRACT

The design of analog electronics learning media applications needs quality analysis. ISO 25010 is one of the standard references in measuring the quality of an Android-based application product. Analysis that can be done is by testing the compatibility and performance efficiency aspect of the media being developed. This study uses a Research and Development (R\&D) method with the ADDIE development model which will produced a quality analog electronics learning media application. Data collection was conducted used a cloud testing and direct testing. Before data collection was conducted validity of media by expert judgement. The results showed that media is "valid" and the quality of the compatibility aspect this media learning was supported on more than 208 smartphones android device and performance efficiency predicate "Satisfied" so that the application could be used for the learning process during the COVID-19 pandemic or tested on other quality aspects.

This is an open access article under the CC-BY-SA license.

\section{Introduction}

In the era of the education revolution 4.0, there are demands on teachers to develop technologybased learning media that meet quality standards, as the application of technology in education can be exciting opportunities that can potentially transform society for the better (Xing, 2017). Lecturers and students should apply education 4.0 principles in order to help the students to compete in the era of 4.0 (Candradewi, 2018).

The Minister of Education and Culture said the condition of the COVID-19 Pandemic did not allow teaching and learning activities to take place normally. There are hundreds of thousands of schools closed to prevent the spread, around 68 million students are carrying out learning activities from home, and around four million teachers carrying out remote teaching activities (Mendikbud, 2020). This is in line with lecture activities, so universities must also conduct distance learning programs.

The Indonesian Internet Service Providers Association (APJII) shows that, in 2018, 171.1 million people in Indonesia were internet users, the Smartphone brand used for internet access 
was Samsung (35.2\%), Oppo (21.1\%), Xiaomi (18.6\%), Vivo (10.4\%), iPhone (3.4\%), Asus (2.4), and others $(8.9 \%)$. and the most used social messaging application is Whatsapp messenger with a percentage of 91.5\%. Based on the Global State StatCounter for the period Maret 2020 to Maret 2021, in Indonesia the smartphone market was as follows: Android system $91.84 \%$, IOs 7.93\%, and other $0.23 \%$.

It was noted by Vaugan (2011) that the combination of text, art, sound, animation, and video sent to users by computers or other manipulated electronic or digital means is considered as multimedia. UNESCO (2014) adds that m-learning as mobile learning involves the use of mobile technology either alone or in combination with information and other communication technologies, and thus allows learning anytime and anywhere. Based on the Global State StatCounter for the period Maret 2020 to Maret 2021, in Indonesia the smartphone market was as follows: Android system $91.84 \%$, IOs 7.93\%, and other $0.23 \%$

Branch (2009) explained that the model Analyze, Design, Develop, Implement, and Evaluate (ADDIE) is a learning planning design model that emphasizes student-centered, innovative, authentic, and inspiring. In addition, the ADDIE model can be used to develop educational products and learning resources. In connection, Khaharsyah (2019) also stated that research on the development of Android-based learning media can use the ADDIE development model and and software for build the appliacation with adobe flash CS6. Similarly, Nurpiena, et.al. (2019) found that the research process for the development of Android-based learning media can use the ADDIE model and Adobe Flash CS6. Andriani, et al. (2021) uses the adobe flash CS6 application to develop mobile learning so as to produce effective media.

Software testing is a process of executing a software product on input data and output data analysis (Mili, 2015). Suman (2014) explained that the main purpose of software engineering is of high quality and sustainable for use. Several years before, Panovski (2008) suggested that in the process of analyzing a software product there are significant differences between application software products and software development products.

Software quality standards, including ISO 9126, ISO 25010, McCall Model, DROMEY, and FURP, are international standard models used in measuring software quality. Hidayati, et. al.(2009) described ISO 9126 as a standard used as a quality model in developing learning media applications. However, in 2012 ISO 9126 evolved to ISO 25010, so the quality test was better when using ISO 25010 (ISO/IEC, 2011).

According to Wagner (2013), ISO 25010 establishes eight aspects of product quality standards: functional suitability, reliability, performance efficiency, usability, maintainability, security, compatibility, and portability. David (2011) proposed that the quality analysis used in software product research with the Android platform can use four of these eight aspects: 
functional suitability, compatibility, usability, and performance. Acharya and Sinha (2013) explained for assessing of m-learning can be following the ISO/IEC 25010 Software Quality model. Rozi and Kristari (2020) conducted research on the development of Android-based learning media to determine the feasibility level using four aspects of ISO 25010 based on functional suitability, portability, usability and performance efficiency aspects. Similarly, Nurpiena, et.al. (2019) used ADDIE development model and ISO 25010 quality model with functional suitability, usability aspects, portability aspects, and validation of media. In literature review of Deta, et.al. (2021) explained that during the Covid-19 pandemic, learning media based on Android was needed to help students understanding and proven to be effective can be accessed by students easily.

Therefore, a summary of the above description is that the Indonesian education Minister made a statement concerning developments of the evolution of education 4.0 which might be associated with the increased use of Android smartphones and the COVID-19 pandemic. requires teachers / lecturers to have quality learning media based on smartphones. So, research needs to produce quality media.

Based on this problem, this study focuses on validity of learning media and obtaining quality products based on ISO 25010 standards, by validation of media and quality analysis the products on aspects of compatibility and performance efficiency. The product this study can be used for the learning process during the COVID-19 pandemic.

\section{Method}

This study uses a Research and Development (R\&D) methods with the ADDIE learning design development model. The purpose of this research and development is to produce quality products according to ISO 25010. Analysis of the quality of the products used in this study are aspects of compatibility and aspects of performance efficiency (Rahadian et.al., 2021). The process of developing learning media designed to resemble the most popular messenger application interface in the world of Whatsapp Messenger. On April 21, 2021, the Whatsapp Messenger application was ranked first with a score of 4.2 (Google Play Store, 2021). This development follows the provisions of the material design concept by Google. The ADDIE model phase in this study was conducted in stages through a revision process in each section so as to produce media that emphasizes student-centered, innovative, authentic, and inspiring (Branch, 2009).

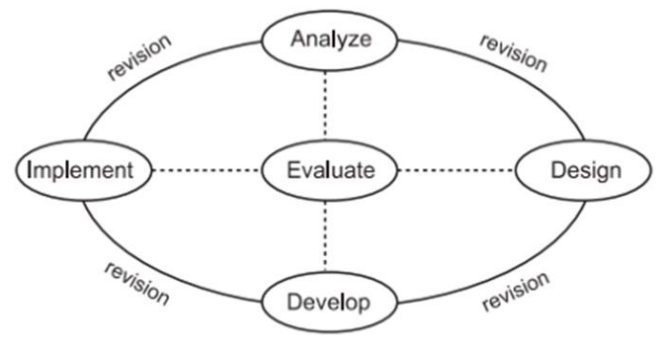

Figure 1. ADDIE Model Phase 


\section{Analyze}

Online learning is a necessity during the Covid19 pandemic, so that lecturers are required to be creative in developing media. The researcher, in this case, conducted a pre-survey on the electronic engineering vocational education study program universitas ahmad dahlan. The things that were done in this pre-survey included: (1) identifying subjects that need learning media; (2) obtaining curriculum information or RPS used; (3) obtaining and identifying subject matter; (4) obtaining media information data used; (5) determining the application for development that is suitable for the media.

\section{Design}

Analog Electronics learning media are designed with learning materials in accordance with the curriculum by the electronic engineering vocational education study program. The layout is designed to resemble the Whatsapp Messenger application was named ENA-PVTE. These design stages included (1) a design a use case diagram, (2) design a flowchart, and (3) design the user interface.

\section{Develop}

The development stage was conducted by preparing the content of the learning material and determining the media developed. The media developed in this study is an application media platform for Android, that designs processes for an Adobe Flash CS6 application using adobe Integrated Runtime(AIR) version 30 (Brossier 2011). The product was tested limited to find out the validity based on judgments from experts on learning the material and the media. The process for the validity of the learning media was tested using the SPSS application (George \& Mallery, 2003)

\section{Implement}

The implementation phase was conducted with cloud testing on compatibility and performance efficiency aspects. After cloud testing was completed and there were no more revisions, the learning media can be used for learning to students (Rahadian et.al., 2021).

\section{Evaluate}

After the implementation phase and data validation was obtained from the products then the final development phase was the quality evaluation of the media. The Quality analysis with ISO 25010 analysis procedures on aspects of compatibility, and performance efficiency (Niknejad, 2011).

\section{Result and Discussion}

In general, the research results of application design and quality analysis on the aspects of compatibility and aspects of performance efficiency. The results of designing analog electronics 
learning media using software Adobe Flash CS 6 can be seen in Figure 2.

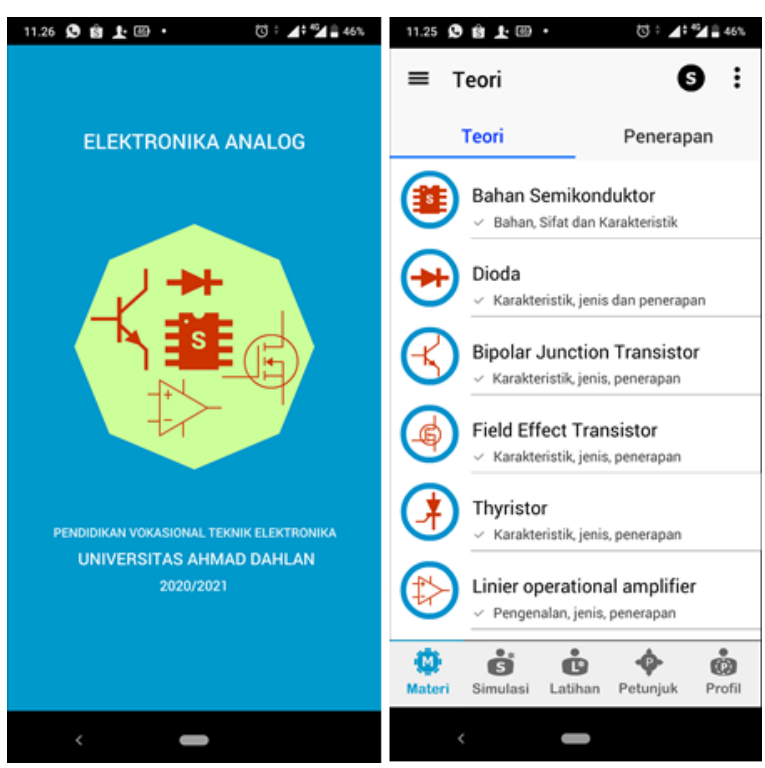

Figure 2. Main menu of analog electronics application

This application has reached a validation value as did Nurpiena, et al. (2019) and Khaharsyah (2019). The validity of the applications performed by media experts based on SPSS calcullations show "very feasible", with a mean score of 4.49 (George D. \& Mallery P. ,2003). In addition, $100 \%$ of subject matter experts scored the validity as "valid".

\section{Compatibility Testing}

The result of compatibility online testing on amazon developers show more than 208 devices supported. Compatibility of online testing on http://.cloud.bitbar.com (Bitbar, 2021) is shown in table 1 . Direct compatibility testing in table 2 .

Table 1. Compatibility online testing

\begin{tabular}{|c|c|c|c|}
\hline No & Smartphone & Version & Result \\
\hline 1 & LG Nexus 7 & 5.1 .1 & Running \\
\hline 2 & LG Google Nexus 5 & 6.0 .1 & Running \\
\hline 3 & Motorola Google Nexus 6 & 6.0 .1 & Running \\
\hline 4 & Motorola Google Nexus 6 & 7.0.1 & Running \\
\hline 5 & Google Pixel 3a & 10.0 & Running \\
\hline \multicolumn{4}{|c|}{ Table 2. Compatibility direct testing } \\
\hline No & Smartphone & Version & Result \\
\hline 1 & Samsung M10 & 10.0 & Running \\
\hline 2 & Samsung J3 Pro & 10.0 & Running \\
\hline 3 & Asus Zenfone Max Pro M1 & 9.0 & Running \\
\hline 4 & Huawei honor S10 & 9.0 & Running \\
\hline 5 & Realme C11 & 9.0 & Running \\
\hline 6 & Xiomi Note 7 & 10.0 & Running \\
\hline 7 & Vivo Y50 & 10.0 & Running \\
\hline
\end{tabular}

The compatibility testing shows the applications were found to be $100 \%$ compatible and 
supported on any smartphones. So there are no obstacles to implementation. This media shows Multiple application co-existence, so that it meets the criteria for compatibility aspects (Acharya \& Sinha, 2013).

\section{Performance Efficiency Testing}

Performance efficiency testing is carried out by looking at the application start time until it is ready to run the analog electronics learning media application online on http://.cloud.bitbar.com (Bitbar, 2021) with different times and an internet connection using the same provider on Figure 3 shows the application has an average score of 4.92 seconds, so it gets the predicate of "satisfied", as suggested by Hoxmeier (2000).

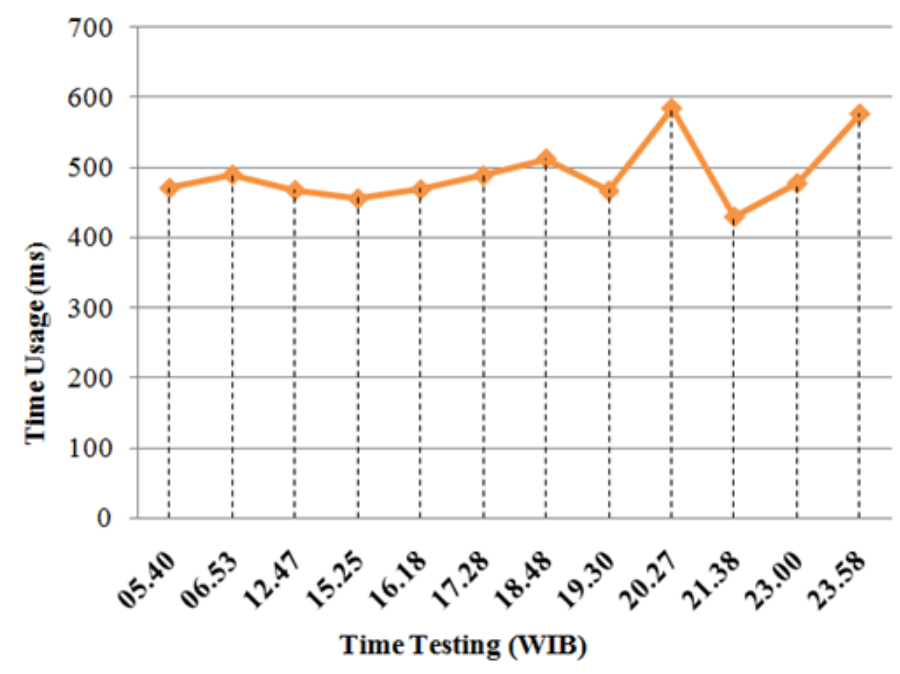

\section{Conclusion}

Figure 3. Performance efficiency testing

Based on the results of the research can be concluded as follows:

1. Quality analysis of analog electronics learning media on compatibility aspects can operated on more than 208 devices.

2. The level on aspects performance efficiency shows the quality of analog electronics learning media have the predicate "satisfied".

3. This learning media application can be applied to the analog electronics learning process and further research can be carried out to determine its effectiveness in the learning process

\section{Acknowledgement}

1. This research was supported by Study Program of Electronics Engineering Vocational Education Universitas Ahmad Dahlan

2. The authors would like to thank the Universitas Ahmad Dahlan

3. The authors would like to thank the team editor JOVES 


\section{References}

Acharya, A., \& Sinha, D. (2013). Assessing the quality of m-learning systems using ISO/IEC 25010. International Journal of Advanced Computer Research, 3(3), 67.

Andriani, A. A., Sultan, A. D., Rufaida, S., \& Nurfadilah, N. (2021). Development of Physics Learning Media Based-Mobile Learning Using Adobe Flash CS6 at Muhammadiyah University of Makassar. Jurnal Pendidikan Fisika, 9(1), 91-97.

APJII. (2020). Report of the Survey Internet APJII 2019-2020.Retrieved from https://apjii.or.id/ Bitbar. (2021). Performance efficiency online testing. Retrived from https://cloud.bitbar.com/ Branch, R.M. (2009). Instructional Design: The ADDIE Approach. New York: Springer.

Brossier, V. (2011). Developing Android Applications With Adobe AIR. USA: O'Reilly Media, inc. Candradewi. (2018). Promoting Education 4.0 in English for Survival Class: What are the Challenges? Journal of English Language, Literature, and Teaching, METATHESIS Vol 2(1):12

David, A. B. (2011). Mobile Application Testing Best Practices to Ensure Quality -AMDOCS. $\begin{array}{ll}\text { Retrieved from } & \text { from }\end{array}$ http://www.globaltelecomsbusiness.com/pdf/AMDOCS\%20WHITEPAPER_\%20Mobile\% 20application\%20testing\%20whitepaper.pdf

Deta, U. A., Kurniawan, F. K., Lestari, N. A., Yantidewi, M., Jauhariyah, M. N. R., \& Prahani, B. K. (2021, March). Literature Review on The Use of Educational Physics Games in Improving Learning Outcomes. In Journal of Physics: Conference Series (Vol. 1805, No. 1, p. 012038). IOP Publishing.

Developer Amazon. (2021). Compatibility online testing. Retrived from https://developer.amazon.com/

George D. \& Mallery P. (2003). SPSS for Windows step by step: A simple reference 11.0 update (4th ed.). Boston : Allyn \& Bacon.

Google Play Store, (2021). Messenger Application detail. Retrieved from https://play.google.com/ store/apps/detail?id

Hidayati, A., Sarwosri,\& Ririd, A.R. T. H., (2009). Analysis of the Development of a Hierarchical Structured Quality Model with ISO 9126 Customization for B2B Software Application Evaluation. Research Report ITS Surabaya, Indonesia.

Hoxmeier J.A. \& Dicesare C. (2000). System respon Time and User Satisfication: An Experiental Study of Browser Base Aplications. AMCIS 2000 Proceedings, page 143. Retrieved from http://www.collector.org/achives/2000_april/03.pdf

ISO/IEC. (2011). Systems and software engineering - systems and software quality requirements and evaluation (SQuaRE) - system and software quality models (2011). Retrieved from https://www.iso.org/obp/ui/\#iso:std:iso-iec:25010:ed-1:v1:en 
Khaharsyah, A. (2019, November). The Development of Android-Based Learning Media for Light Vehicle Engineering Skill Students of SMKNegeri 2 Pengasih. In Journal of Physics: Conference Series (Vol. 1273, No. 1, p. 012007). IOP Publishing.

Mendikbud (2020). Adjustment of the Joint Decree of the Four Ministers on Learning Guidelines during the COVID-19 Pandemic. Retrieved from https://www.kemdikbud.go.id/

Mili. A. \& Tchier, F. (2015). Software Testing - Concept and Operations. USA: John Wiley \& Sons,Inc.

Niknejad, A. (2011). A Quality Evaluation of an Android Smartphone Application. Retrived from https://gupea.ub.gu.se/bitstream/2077/26728/1/gupea_2077_26728_1.pdf

Nurpiena, S. A., Wihidayat, E. S., \& Budianto, A. Developing Indonesia Sign Language (BISINDO) Application with Android Based for Learning Sign Language. Journal of Informatics and Vocational Education, 4(1).

Panovski, G. (2008). Product Software Quality. Unpublished thesis, Department of Mathematics and Computing Science, Technische Universiteit Eindhoven, Germany

Rahadian, D., Hamdani, N. A., Gunawan, R. H., Bariyah, S. H., \& Purwanti, Y. (2021, March). Development Presensi PTI based on android with Quick Response code. In IOP Conference Series: Materials Science and Engineering (Vol. 1098, No. 3, p. 032094). IOP Publishing.

Rozi, F., \& Kristari, A. (2020). Pengembangan Media Pembelajaran Game Edukasi Berbasis Android pada Mata Pelajaran Fisika untuk Siswa Kelas XI di SMAN 1 Tulungagung. JIPI (Jurnal Ilmiah Penelitian dan Pembelajaran Informatika), 5(1), 35-44.

StatCounter. (2021). Mobile \& Tablet Android Version Market Share Worldwide. Retrieved from https://gs.statcounter.com/os-market-share/mobile/indonesia

Suman, M. W. (2014). A Comparative Study of Software Quality Models. International Journal of Computer Science and Information Technologies (IJCSIT), Vol. 5(4): 5634

UNESCO. (2014). Mobile Learning. Retrieved from http://www.unesco.org/new/en/unesco /themes/icts/m4ed/

Vaugan, T. (2011). Multimedia: Making it Work - Eihgth Edition. USA: McGraw-Hill

Wagner, S. (2013). Software Product Quality Control. New York: Springer.

Xing B. \& Marwala T. (2017). Implications of the Fourth Industrial Age on Higher Education. Retrieved from https://www.researchgate.net/publication/315682580_Implications_of_ the_Fourth_Industrial_Age_on_Higher_Education. 